\title{
DECOMPOSITION AND NUTRIENT RELEASE BY AVICENNIA MARINA (FORSK.) VIERH. IN A MANGROVE ISLET AND A BRUSHPILE IN NEGOMBO ESTUARY
}

\author{
L. PINTO ${ }^{* *}$ and P.A. SWARNAMALI ${ }^{2}$ \\ ${ }^{1}$ Department of Zoology, Open University of Sri Lanka, Nawala \\ ${ }^{2}$ Department of Botany, University of Sri Jayewardenepura, Nugegoda
}

(Received: 14 May 1996; accepted: 5 Șeptember 1997)

\begin{abstract}
Decomposition rates of dry and fresh Avicennia marina leaves in a mangrove islet and a brushpile in Negombo Estuary were investigated for 3 months using litter bags. The highest decomposition rate $(k)$ was recorded for fresh leaves in the estuary $(\mathrm{k}=0.032)$ and the lowest for dry leaves in the forest $(\mathrm{k}=0.013)$. About 9 weeks were required for $50 \%$ decomposition of dry leaves in the forest, but only 3 weeks were necessary for fresh leaves in the estuary to reach the same level of decomposition. Within one month, $90 \%$ of $\mathrm{N}, \mathrm{P}$ and $\mathrm{K}$ in the fresh leaves were released to the estuary. The nitrogen enrichment was significant in the fresh and dry leaves in the forest after 7 weeks. $N$ and $P$ release were slow but $\mathrm{K}$ release was fast.
\end{abstract}

Key words: Avicennia marina, brushpiles, decomposition, litter, mangroves, Negombo estuary, nutrients.

\section{INTRODUCTION}

Grazing, decomposition and tidal export are the important processes by which nutrients in the mangrove litter are cycled and transported. The nutrient dynamic process that takes precedence in a specific mangrove habitat is determined by a number of factors of that habitat, which includes the amount of litter, the abundance of grazers and microfauna, soil characteristics, tide and elevation. In the Negombo Estuary where the tidal fluctuation is low and fishermen use mangrove twigs in brushpile fishery, probably decomposition and aquatic grazing food-chains play a major role in nutrient dynamics. Studies on litter decomposition are important to the Negombo Estuary because of this unique method of fishing, ${ }^{1}$ and since $80 \%$ of estuary's catch is attributed to brushpile fishery. ${ }^{2}$ Fishermen use mainly Avicennia marina and Lumnitzera racemosa twigs to make their brushpiles. Degradation of Avicennia marina leaves under laboratory conditions ${ }^{3}$ and field conditions has been documented in Australia, ${ }^{4,5}$ New Zealand, ${ }^{6,7}$ Philippines, ${ }^{8,9}$ Thailand ${ }^{10,11}$ and South Africa, ${ }^{12}$ but no published information is available for mangroves of this region. This study was undertaken to compare the rate of decomposition of mangrove litter in the forest and in the estuary. The study also extends to the patterns of $\mathrm{N}, \mathrm{P}$ and $\mathrm{K}$ release during the decomposition of mangrove leaves in the forest and estuary.

"Present address: Australian Water Technologies, P.O. Box 73, West Ryde, NSW 2114, Australia. 


\section{METHODS AND MATERIALS}

This study was conducted in Negombo Estuary, (latitude $7^{\circ} 11^{\prime} \mathrm{N}$ and longitude $79^{\circ} 50^{\prime} \mathrm{E}$ ) in the west coast of Sri Lanka (Fig. 1). The field experiment was carried out in Mandagas-alamba, an islet located in the northern estuary and in a nearby brushpile. The distribution of mangroves in this islet has been mapped out and Avicennia marina is reported to be the dominant species, which together with Ceriops tagal covers 3.2 ha of the islet. ${ }^{13}$ The salinity variation of the estuary during the study period was from $11 \mathrm{ppt}$ - 32ppt. Monthly rainfall was comparatively low from 0 to $149 \mathrm{~mm}$. Diurnal water temperature during the sampling time fluctuated from $32^{\circ} \mathrm{C}$ to $35^{\circ} \mathrm{C}$ and dissolved oxygen from 8 to $10 \mathrm{mg} \mathrm{l}^{-1}$.

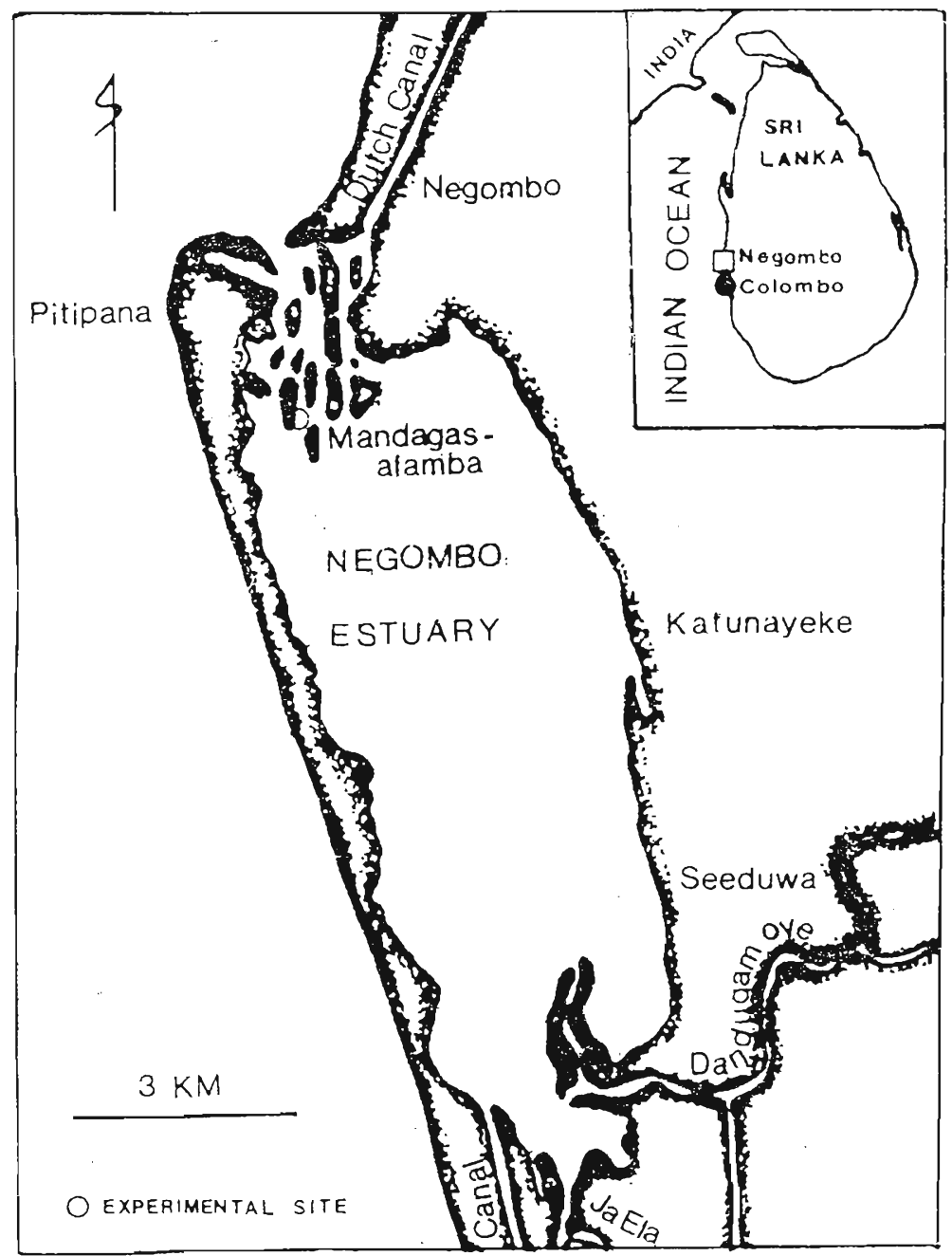

Figure 1: The experimental site in the Negombo Estuary. 
This field experiment was designed to compare the terrestrial and aquatic decomposition of fresh and dry mangrove leaves. The litter decomposition was determined using $20 \times 30 \mathrm{~cm}^{2}$ nylon net litter bags of $5 \mathrm{~mm}$ mesh size as in other investigations. ${ }^{14}$ An earlier study has shown that there is no significant difference in decomposition rates of Avicennia marina leaves determined, using $7 \mathrm{~mm}$ and $1 \mathrm{~mm}$ mesh litter bags. ${ }^{4}$ This mesh size, while retaining leaf fragments in water allowed crabs to nibble on litter. Smail sesarmid crabs, Chiromates darwinensis, $C$. indiarum and $C$. bidens, with orbital widths 3.5-17.5 mm occur in this mangrove habitat ${ }^{15}$ and their impact on decomposition was not excluded by this mesh size. Juvenile crustaceans and fish could nibble litter in bags in the aquatic habitat, thus their contribution was also included in the decomposition process.

The fresh green leaves for the experiment were plucked from plants. They included young, intermediate and old leaves. Dry leaves were collected from the litter surface. Only the recently fallen, non-fragmented leaves from the upper layers of litter were used in bags. Since a preliminary investigation showed that fresh leaves were 3 times heavier than dry leaves, the weight of the bags with fresh leaves was made 3 times heavier than dry leaves.

Twenty litter bags with $300 \mathrm{~g}$ of dry leaves and $100 \mathrm{~g}$ of fresh leaves were deployed in the field as follows:

1. Ten litter bags with fresh leaves in the forest

2. Ten litter bags with dry leaves in the forest

3. Ten litter bags with fresh leaves in the estuary (brushpile)

4. Ten litter bags with dry leaves in the estuary (brushpile)

At first, the bags were removed every two weeks, but later at monthly intervals. This experiment was conducted from March to June 1987. The bags were gently washed to remove silt and the leaves were dried at $70^{\circ} \mathrm{C}$ to constant weight.

The following equation for litter decomposition ${ }^{16}$ was used to compare decomposition rates under 4 different conditons.

$$
d X / d t=L-k X
$$

$\mathrm{dX}$ is a small change in time $t, \mathrm{~L}$ is the incoming litter, $\mathrm{X}$ is the litter present and $\mathrm{k}$ is the instantaneous rate of litter decay. Under the current experimental conditions, the equation takes the form,

$$
\mathrm{dX} / \mathrm{dt}=-\mathrm{k} / \mathrm{X} \text { or } \mathrm{X}_{\mathrm{t}}=\mathrm{X}_{0} \mathrm{e}^{-\mathrm{kt}}
$$

where $X_{0}$ is the initial weight of litter and $X_{t}$ is the weight after a time $t$. 
Potassium content was determined by flame photometer, total $\mathrm{N}$ by MicroKjeldhal method and $\mathrm{P}$ colorimetrically by molybdate method. ${ }^{17}$ All analyses were done at the University of Sri Jayewardenepura. Mean unit weights of $N$, $\mathrm{P}$ and $\mathrm{K}$ in leaves under different conditions and time were determined from 3 samples at every instance.

\section{RESULTS}

Decomposition: The percentage weight loss of dry and fresh leaves of Avicennia marina in the estuary and in the forest, during the study period is shown in Fig. 2. This figure also gives the decay constants $(\mathrm{k})$ for the decomposition of dry and fresh leaves in the two habitats. Accordingly, the highest decomposition was observed for fresh leaves in the estuary $(k=0.032)$ and lowest for dry leaves in the forest ( $\mathrm{k}=0.013$ ). In general, decomposition was highest in the estuary than in the forest and in fresh leaves than in dry leaves. However, analysis of variance (ANOVA) indicated that there was no significant difference ( $\mathrm{df}=3, \mathrm{~F}=3.86$; p>0.05) between the treatments.

Nutrients: N, P and $\mathrm{K}$ per unit weight of dry and fresh leaves in the forest and estuary at different times of sampling are given in Table 1 . From these values the weights of $\mathrm{N}, \mathrm{P}$ and $\mathrm{K}$ in litter bags were computed. The unit weight of $\mathrm{K}$ decreased with time, but the unit weight of $\mathrm{N}$ and $\mathrm{P}$ in dry leaves in the forest floor decreased initially and then increased after 23 days.

Figure 3 shows the percentages of the remaining N, P and $\mathrm{K}$ in the litter bags. According to this figure the nutrient release is rapid in the estuary but slow in the forest. The release of $\mathrm{K}$ is faster than the release of $\mathrm{N}$ and $\mathrm{P}$. In 3 weeks $90 \%$ of $\mathrm{K}$ was released from the leaves kept in the estuary, whereas for $\mathrm{N}$ and $\mathrm{P}$ it has taken 7 weeks for the release of the same percentage.

\section{DISCUSSION}

Ecosystem processes: There is a conflict of opinion on the major process that governs the transfer of nutrients from mangrove plants to the environment. While grazing food chains dominate the process in some mangroves, ${ }^{18,19}$ detritus food chains are important in others. ${ }^{20}$ As tidal influence decreases, as it is the case in Negombo Estuary, the litter decomposition and accumulation become more important ${ }^{21}$ and detritus food chains take precedence over grazing food chains. The use of mangroves in brushpile fishery, further contributes to the decomposition of litter in brushpiles. Probably leaf fragments settle close to brushpiles and decompose there, since they are constructed in areas of low tidal energy. 


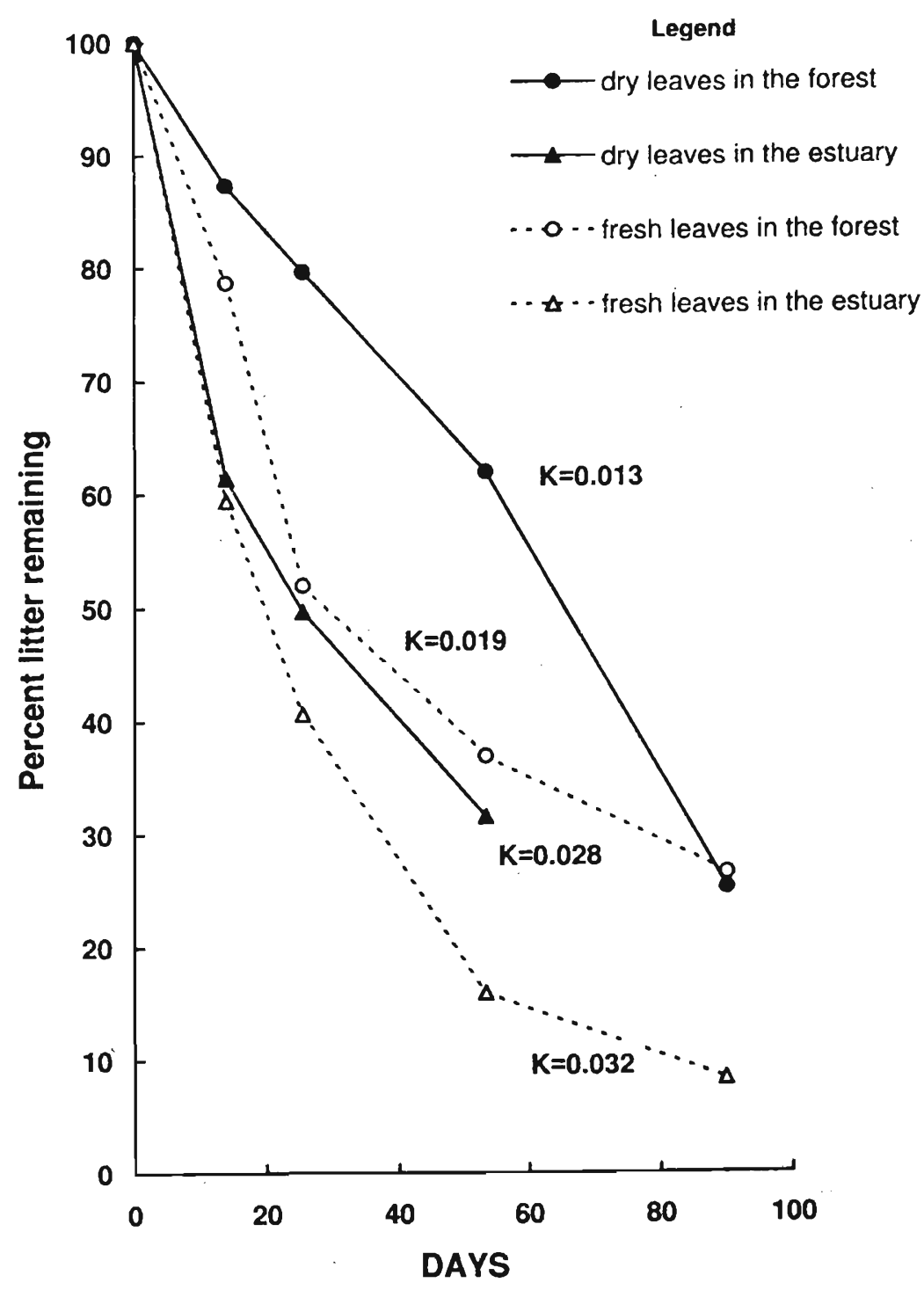

Figure 2: The mean percentage weight loss in litter bags containing dry and fresh leaves in the mangrove forest and brushpiles. 

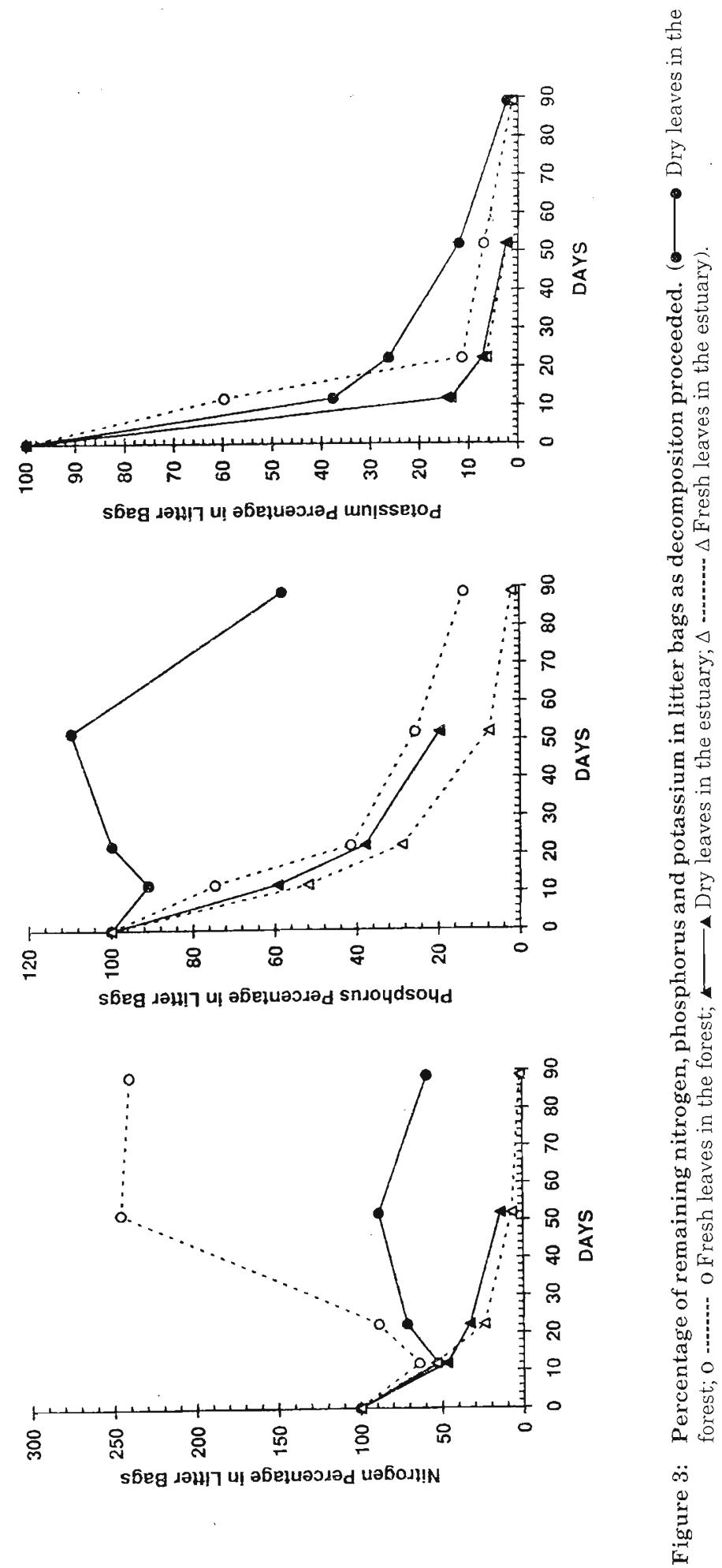
Table 1: Percentage of $\mathrm{N}, \mathrm{P}$ and $\mathrm{K}$ in decomposing Avicennia marina leaves.

\begin{tabular}{|c|c|c|c|c|}
\hline $\begin{array}{l}\text { Type of } \\
\text { leaves/ } \\
\text { habitat }\end{array}$ & $\begin{array}{c}\text { Decomposing } \\
\text { time (days) }\end{array}$ & $\mathrm{N}$ & $\mathrm{P}$ & $\mathrm{K}$ \\
\hline Dry & 0 & 0.54 & 0.024 & 3.00 \\
\hline leaves & 12 & 0.43 & 0.022 & 0.72 \\
\hline in the & 23 & 0.37 & 0.019 & 0.44 \\
\hline estuary & 52 & 0.22 & 0.016 & 0.22 \\
\hline Dry & 0 & 0.54 & 0.024 & 3.00 \\
\hline leaves & 12 & 0.32 & 0.021 & 1.30 \\
\hline in the & 23 & 0.48 & 0.029 & 1.00 \\
\hline \multirow[t]{2}{*}{ forest } & 52 & 0.77 & 0.042 & 0.50 \\
\hline & 89 & 1.29 & 0.054 & 0.28 \\
\hline Fresh & 0 & 0.26 & 0.072 & 2.22 \\
\hline leaves & 12 & 0.23 & 0.063 & 0.56 \\
\hline in the & 23 & 0.16 & 0.048 & 0.38 \\
\hline \multirow[t]{2}{*}{ estuary } & 52 & 0.12 & 0.032 & 0.35 \\
\hline & 89 & 0.05 & 0.018 & 0.30 \\
\hline Fresh & 0 & 0.26 & 0.072 & 2.22 \\
\hline leaves & 12 & 0.21 & 0.067 & 1.70 \\
\hline in the & 23 & 0.44 & 0.052 & 0.50 \\
\hline \multirow[t]{2}{*}{ forest } & 52 & 1.7 & 0.049 & 0.44 \\
\hline & 89 & 2.41 & 0.036 & 0.11 \\
\hline
\end{tabular}

Decomposition: It has been observed that litter decomposition rates exhibit habitat-specific and species-specific differences. ${ }^{22}$ In this study, the decomposition of mangrove leaves in the estuary was higher than that on land similar to Avicennia alba and Scyphiphora heterophyllacea in the Philippines. ${ }^{8,9}$ Dry mangrove leaves decay at a slower rate than fresh leaves as in other aquatic plants. ${ }^{23}$

The decay constant $\mathrm{k}$ can be used to compare decay rates, higher $\mathrm{k}$-values being an indication of higher decomposition rates. Leaves are reported to have a higher $\mathrm{k}$ value than twigs and branches of the same species. ${ }^{24}$ Besides environmental factors and leaf structure, $\mathrm{k}$ values may be influenced by the mesh size of the litter bags and the duration of the experiment. Some studies have utilised litter bags of mesh size, $1 \mathrm{~mm},{ }^{24} 2 \mathrm{~mm}^{25}, 3 \mathrm{~mm}^{26}$ and $7 \mathrm{~mm}$. While 
the small mesh sizes reduce the role of crabs in decomposition, large mesh sizes enhance the leaching of leaf fragments in late decomposition. Size, morphology and texture of leaves are important in selecting the mesh size. Previous studies on Avicennia marina leaves have indicated that 1 to $7 \mathrm{~mm}$ mesh size is suitable for this species. In this experiment, the deviation from exponential decay equation, observed for the dry leaves in the forest is probably due to the late rapid leaching or the influence of some environmental factors. Decomposition is rapid during the first few months and more than $70 \%$ decomposition was completed within the first 90 days .

The k-values recorded for mangroves in this study are comparable with those recorded for macrophytes in Hudson Estuary, which ranged from 0.0024 in Typha angustifolia to 0.0133 in Potamogeton sp. ${ }^{24}$ In spite of the less amenable leaf chemistry of mangroves for decomposition, compared to these macrophytes, the slightly higher $\mathrm{k}$-values recorded for mangroves could be due to high ambient temperature in the mangrove habitat. Sedges and willows are reported to have high $\mathrm{k}$ values $(\mathrm{k}=0.261$ to 0.316$){ }^{25}$ The $\mathrm{k}$ values recorded for rain forests of Sri Lanka are higher than those recorded for mangroves in the current study. ${ }^{26}$ The reference to $\mathrm{k}$-values in this study is indicative rather than conclusive, due to the small number of samples.

It takes only 3 weeks for $50 \%$ decomposition to occur in fresh leaves in Negombo Estuary, whereas for dry leaves in the forest it takes 9 weeks, indicating that, brushpile fishery enhanced litter decomposition. Both in Sri Lanka and in Thailand about 3 weeks were required for $50 \%$ decomposition of Avicennia marina leaves in water. ${ }^{10}$ However, in the Philippines more than 8 weeks were required for $50 \%$ decomposition in dry Avicennia alba leaves. ${ }^{9}$ For $50 \%$ decomposition in dry Avicennia marina it has taken 8 weeks in Sydney Harbour ${ }^{4}$ and 6-8 weeks in New Zealand. ${ }^{7}$

Nutrients: N, P and $\mathrm{K}$ are essential elements for plants and are described as macronutrients. $\mathrm{N}$ and $\mathrm{K}$ percentages in Avicennia marina leaves recorded in this study are in the middle range of percentages recorded for terrestrial plants and $\mathrm{P}$ value towards the lower limit of the range. ${ }^{27} \mathrm{~A}$. marina leaves in the current study recorded lower percentages of $\mathrm{N}$ and $\mathrm{P}$ compared to those of $A$. alba in the Philippine ${ }^{28}$ and $A$. marina in Australia, ${ }^{29}$ but the K percentage was higher than that in the Philippines and Australia. Seedlings of A. marina are reported to uptake potassium preferentially over a wide range of external sodium concentrations. ${ }^{30}$ Further, the same report stated that $A$. marina like A. officinalis is an obligate halophyte with optimum growth at salinity range of 58-290 mM chloride (50-250 mM sodium). From A. marina seedlings grown in culture solutions it was found that, potassium had an intermediate level of accumulation between the high sodium accumulation and the low calcium and magnesium accumulation. ${ }^{31}$ Potassium accumulation was highest in $75 \%$ sea 
water but low in $100 \%, 50 \%, 25 \%$ and $0 \%$ sea water. While physiological processes accumulated nutrients in different parts of the plant, the overall nutrient level in the entire plant may indicate the nutrient composition of soil and water. The knowledge of such information is useful to evaluate whether the relatively small size of mangrove plants in Sri Lanka is due to soil chemistry or other factors, such as low tidal fluctuation and paucity in tidal forest management.

In 7 Australian mangrove species namely, Aegiceras corniculatum, Avicennia marina, Ceriops tagal, Excoecaria agallocha, Osbornia octodonta, Rhizophora stylosa and Xylocarpus australasicus, nitrogen percentage ranged from 0.78 to 1.85 , phosphorus percentage from 0.09 to 0.21 and potassium percentage from 0.48 to $1.79 .{ }^{29}$ In the Philippines the percentage of nitrogen in leaves of Avicennia alba, Ceriops decandra, Scyphiphora hydrophyllaceae, Excoecaria agallocha and Lumnitzera littorea ranged from 0.52 to 1.03, phosphorus from 0.05 to 0.11 and potassium from 0.27 to 0.74 . Percentages of $\mathrm{N}$ and $\mathrm{P}$ in the leaves of Rhizophora apiculta -from Malaysian mangroves were comparable with those in the current study. ${ }^{32}$ But the percentage of potassium in the leaves of $A$. marina from Sri Lanka, was higher than that of $R$. apiculata from Malaysia. The differences in the leaf nutrient percentages may be due to soil conditions, age, species and the leaf chemistry. For the analysis of Australian mangrove leaves, mature but not senescent leaves from North Queensland were taken. ${ }^{29}$ In the Philippines, samples were collected from monthly litter accumulated in baskets. ${ }^{28}$ In the current study, the dry leaves were picked from the forest floor, and the fresh leaves were plucked from trees. A decrease in leaf nitrogen during senescence and an increase in the absolute nitrogen ofleaflitter during decomposition has been observed in the mangroves of Florida. ${ }^{21}$

Initial concentrations of elements in plant tissue vary from species to species. However, rate of leaching of a particular element from different species of plants generally remains the same, because of the way specific elements are incorporated in organic matter. As in previous studies with wetland species, potassium leached out of mangrove leaves rapidly. ${ }^{25.33}$ Since potassium is not a structural part of plant tissues, rapid leaching of $K$ is to be expected.

Similar to previous studies ${ }^{10,14}$ nitrogen enrichment with decomposition, was observed for leaves in the forest after 7 weeks. Nitrogen and phosphorus enrichment is probably due to microbial activity while its initial drop could be due to the release of tannins that makes the colonisation difficult. ${ }^{34}$ Nitrogen thus accumulated in the mangrove forest floor are reported to be flushed after rains, making about a 10-fold increase in estuarine nitrogen in Malaysia ${ }^{35}$ but slight increase in estuarine nitrogen in Australia. ${ }^{36}$ 
Fresh leaves in the estuary released all the elements investigated at the fastest rate. Within one month, more than 90\% of each element present in litter bags were released. Since the duration of a brushpile is also about a month, it is possible that the nutrients released during this period are utilised by phytoplankton and epiphytic algae in the brushpiles, which further attract fish. Juvenile fish that directly feed on mangrove material are few in this estuary as in the Philippines, ${ }^{37}$ and restricted to a few families such as Syngnathidae. ${ }^{38}$ But in the American mangroves, direct mangrove feeders including mullets have been reported. ${ }^{39}$

Probably a succession of fish and crustacean taxocenes occur with decomposition of mangrove leaves in the brushpile. This is evident from the fact that the dominant fish species in brushpiles after a month, ${ }^{2}$ are different from those captured from areas where fresh mangrove leaf litter has accumulated, after tree felling in this estuary. ${ }^{40}$

Brushpile fishery also deprives the estuary of the benefits of $\mathrm{N}$ and $\mathrm{P}$ enrichment that occur, when leaves decompose in the forest. Some fishermen have the habit of leaving Lumnitzera racemosa twigs on land for sometime, so that plants shed their leaves, before using them in the brushpile. In such a situation, leaf decomposition takes place on land and twig decomposition takes place in water. Since mangroves are heavily exploited in the Negombo Estuary for brushpile fishery, studies are necessary to estimate the biomass of mangroves available, their growth and replacement rates and the current brushpile requirement. Alternatively, Avicennia marina and Lumnitzera racemosa can be planted in plots around the estuary, set aside for extracting twigs for brushpile fishery.

\section{References}

1. Ward J.A. \& Wyman R.L. (1975). The cichlids of the resplendent isle. Oceans 8: 42-27.

2. de Silva S.S. \& Silva E.I.L. (1979). Fish fauna of a coastal lagoon in Sri Lanka: distribution and seasonal variation. Bulletin of the Fisheries Research Station. Sri Lanka 29: 1-9.

3. Chale F.M.M. (1993). Degradation of mangrove leaf litter under aerobic conditions. Hydrobiologia 257: 177-183.

4. Goulter P.F.E. \& Allaway W.G. (1979). Litterfall and decomposition in a mangrove stand, Avicennia marina (Forsk.) Ver. in middle harbour, Sydney. Australian Journal of Marine and Freshwater Research 30:541-546. 
5. Robertson A.I. (1988). Decomposition of mangrove leaf litter in tropical Australia. Journal of Experimental Marine Biology and Ecology 116: 235247.

6. Albright L.J. (1976). In situ degradation of mangrove (Avicennia marina) tissues. New Zealand Journal of Marine Freshwater Research 10: 385-389.

7. Woodroffe C.D. (1982). Litter production and decomposition in the New Zealand mangrove, Avicennia marina var. resinifera. New Zealand Journal of Marine Freshwater Research 16: 176-181.

8. Lomuntad M.A.T. (1984). The change in C:N ratio of decomposing Scyphiphora heterophyllacea leaves in four tidal zones in Pagbilao Mangrove Forest Reserve, Quezon. B.S. (Biology) thesis. De La Salle University, Manila. p. 87.

9. Pajarillo M. R. (1984). Elemental and nutritive analysis of decomposing Avicennia alba leaves in four tidal zones in Pagbilao mangrove forest reserve, Quezon. B.S. (Biology) thesis. De La Salle University, Manila. pp. 48.

10. Boonruang P. (1978). The degradation rates of mangrove leaves of Rhizophora apiculata (Bl.) and Avicennia marina (Forsk.) Vierh. at Phuket Island, Thailand. Phuket Marine Biology Research Bulletin 26: 1-7.

11. Aksornkoae S. \& Khemnark C. (1984). Nutrient cycling in mangrove forest of Thailand. In: Asian Symp. on Mangrove Environment, Research and Management (Eds. E. Soepadmo, A. N. Rao \& D. J. Macintosh). pp. 545-557. UNESCO \& University of Malaya, Kuala Lumpur.

12. Steinke T. D. (1980). Degradation of mangrove leaf and stem tissues in situ in Mgeni Estuary, South Africa. Proc. 2nd Int. Symp. on the Biology and Management of Mangroves and Tropical Shallow Water Communities. Papua New Guinea.

13. Pinto L. (1982). Distribution and zonation of mangroves in the northern part of the Negombo Lagoon (Sri Lanka). Journal of the National Science Council of Sri Lanka 10(2): 245-255.

14. Cruz A.A. de la (1973). The role of tidal marshes in the productivity of coastal waters. Association of Southern Biologists Bulletin 20: 147-156. 
15. Pinto L. (1984). Some ecological aspects of crabs occurring in the mangrove islets of Negombo Lagoon, Sri Lanka. In: Asian Symp. on Mangrove Environment, Research and Management. (Eds. E. Soepadmo, A. N. Rao \& D.J. Macintosh). pp. 311-330 UNESCO \& University of Malaya, Kuala Lumpur.

16. Poole R.W. (1974). An introduction to quantitative ecology. McGraw Hill. pp. 531.

17. Jackson M.L. (1973). Soil chemical analysis. Prentice Hall. pp. 183-226 \& 326-338.

18. Robertson A.I. (1991). Plant-animal interactions and the structure and function of mangrove forest ecosystems. Australian Journal of Ecology 16: $433-443$.

19. Camilleri J.C. (1992). Leaflitter processing by invertebrates in a mangrove forest in Queensland. Marine Biology 114: 139-145.

20. Heald E.J. (1971). The production of organic detritus in a South Florida Estuary. University of Miami Sea Grant Technical Bulletin, No. 6 pp. 110.

21. Twilley R.R., Lugo A.E. \& Patterson-Zucca (1986). Litter production and turnover in basin mangrove forests in southwest Florida. Ecology 67: 670683.

22. Jansen D.H. (1975). Ecology of plants in the tropics. Studies in Biology No. 58. Edward Arnold Pub. pp. 66.

23. Singhal P.K.,Varghese L. \& Talegaonkar L. (1993). Abiotic and microbial decomposition of pre and post bloom leaves of water hyacinth, Eichhornia crassipes (Mart.) Solms. Hydrobiologia 259: 115-119.

24. Bianchi T.S. \& Findlay S. (1991). Decomposition of Hudson Estuary macrophytes: photosynthetic pigment transformations and decay constants. Estuaries 14: 65-73.

25. Chamie J.P.M. \& Richardson C.J. (1978). Decomposition in Northern Wetlands. In: Freshwater wetlands: ecological processes and management potential. (Eds. R. E.D. Good., D.F. Whigham \& R.L. Simpson) pp. 89-97. Academic Press, New York. 
26. Gunatilleke A.I. \& Maheswaran J. (1987). Soil microbial studies in a tropical rain forest and in adjacent deforested areas in Sri Lanka III. Decomposition of leaf litter of dominant tree species. In: Proc. Conf. on Dipterocarpus. (Ed. A.J.H. Kosterman) UNESCO pp. 135-150.

27. Sutchcliffe J. F. \& Baker D.A. (1978). Plants and mineral salts. Studies in Biology No. 48. Edward Arnold Pub. London.

28. Pinto L. (1992). Litterfall and its elemental content in the Pagbilao Mangrove Forest Reserve, Philippines, Mahasagar 25: 97-104.

29. Spain A.V. \& Holt J.A. (1980). The elemental status of the foliage and branchwood of seven mangrove species from Northern Queensland. Divisional Soils Report No.49, CSIRO, Australia.

30. Downton W.J.S. (1982). Growth and osmotic relations of the mangrove Avicennia marina, as influenced by salinity. Australian Journal of Plant Physiology 9: 519-528.

31. Clough B.F. (1984). Growth and salt balance of mangroves Avicennia marina (Forsk.) Vierh. and Rhizophora stylosa Griff. in relation to salinity. Australian Journal of Plant Physiology 11: 419-430.

32. Wong C.H., Ong J.E. \& Gong W. K. (1982). Slash production and nutrient status in a managed mangrove forest in Malaysia. Biotrop special publication No. 17. Proc. Symp. on mangrove forest ecosystem productivity in South-East Asia. pp.61-66.

33. Davis C.B. \& Valk van der A.G. (1978). Litter decomposition in Prairie Glacial marshes. In: Freshwater wetlands: ecological processes and management potential (Eds. R.E.D. Good., D.F. Whigham \& R.L. Simpson) pp. 99-113 Academic Press, New York.

34. Cundell M., Brown M.S., Stanford R. \& Mitchell R. (1978). Microbial degradation of Rhizophora mangle leaves immersed in the sea. Estuarine Coastal Marine Science 9: 281-286.

35. Thong K.L., Sasekumar A. \& Marshall N. (1993). Nitrogen concentrations in a mangrove creek with a large tidal range, Peninsular Malaysia. Hydrobiologia 254: 125-132.

36. Boto K.G. \& Wellington J.T. (1988). Seasonal variation in concentrations and fluxes of dissolved organic and inorganic materials in a tropical, mangrove waterway. Marine Ecology Progress Series 50:151-160. 
37. Pinto L. (1987). Environmental factors influencing the occurrence of juvenile fish in the mangroves of Pagbilao, Philippines. Hydrobiologia 150: 283-301.

38. Pinto L. \& Punchihewa N.N. (1996). Utilisation of mangroves and seagrasses by fishes in the Negombo Estuary, Sri Lanka. Marine Biology 126: 333345 .

39. Odum W.E. \& Heald E.J. (1972). Trophic analysis of an estuarine mangrove community. Bulletin of Marine Science 22: 671-736.

40. Pinto L. \& Punchihewa N.N. (1993). Short-term effects of denudation of mangroves on fish and crustacean communities of the Negombo Lagoon. In: Proc. International and Interdisciplinary Symposium: Ecology and Landscape Management in Sri Lanka. (Eds. W. Erdelen, C. Preu, N. Ishwaran, C. M. Madduma Bandara). Margraf Scientific Books, Germany. pp. 323340. 